\title{
Optimasi Konsentrasi Vaselin Album dan Adeps Lanae pada Formulasi Sediaan Salep Ekstrak Etanol Daun Kersen (Muntingia calabura L.)
}

\author{
Optimization of the Concentration of Vaselin Album and Adeps \\ Lanae in the Formulation of Ethanol Extract Ointment for Kersen \\ Leaf (Muntingia calabura L.)
}

\author{
Baiq Saomi Alfilaili ${ }^{*}$, Wahida Hajrin ${ }^{2}$, Yohanes Juliantoni \\ ${ }^{1}$ Laboratorium Teknologi dan Sediaan Farmasi, Program \\ Studi Farmasi, Fakultas Kedokteran, Universitas \\ Mataram, Jl. Majapahit 62 Mataram 83125, Indonesia \\ *E-mail: saomibaiq@gmail.com
}

\begin{abstract}
Abstrak
Daun kersen (Muntingia calabura L.) mengandung senyawa metabolit sekunder seperti tanin, flavonoid, dan saponin. Senyawa metabolit sekunder ini berfungsi sebagai antibakteri terutama bakteri Staphylococcus epidermidis penyebab jerawat, sehingga dapat dikembangkan menjadi suatu sediaan. Salah satu bentuk sediaan yang dapat dikembangkan yaitu bentuk sediaan salep. Pemilihan konsentrasi basis sangat penting karena dapat mempengaruhi sifat fisik sediaan. Tujuan dari penelitian ini adalah untuk mengetahui komposisi formula optimum salep ekstrak etanol daun kersen dengan variasi konsentrasi vaselin album dan adeps lanae kemudian mengetahui sifat fisik dan tingkat penerimaan konsumen pada formula yang telah dinyatakan optimum. Daun kersen diekstraksi dengan metode maserasi menggunakan pelarut etanol 96\%. Penentuan nilai optimum dilakukan menggunakan metode Simplex Lattice Design yang tersedia dalam software Design Expert Versi 11. Respon yang diukur untuk memperoleh formula optimum ini terdiri atas daya sebar, daya lekat dan $\mathrm{pH}$. Hasil yang diperoleh menunjukkan formula salep yang optimum memiliki komposisi vaselin album dan adeps lanae sebesar $73,29 \%$ dan $9,71 \%$, dengan daya sebar $3,10 \pm 0,12 \mathrm{~cm}$, daya lekat $6,10 \pm 0,53$ detik, $\mathrm{pH}$ $4,78 \pm 0,08$, dan nilai akseptabilitas sebesar 4,02, sehingga dapat disimpulkan bahwa formula yang dinyatakan optimum memiliki sifat fisik yang memenuhi persyaratan dan disukai oleh responden.
\end{abstract}

Kata kunci: Daun kersen (Muntingia calabura L.), Salep, Simplex Lattice Design, ,Vaselin Album, Adeps Lanae 


\begin{abstract}
Cherry leaves (Muntingia calabura L.) contain secondary metabolites such as tannins, flavonoids, and saponins. This secondary metabolite compound functions as an antibacterial, especially Staphylococcus epidermidis bacteria that cause acne, so that it can be developed into a formula. One of the dosage forms that can be developed is the ointment dosage form. The choice of base concentration is very important because it can affect the physical properties and effectiveness of the preparation. The purpose of this study was to determine the optimum composition of the ethanol extract formula of cherry leaves with variations concentration of Vaseline album and adeps lanae, physical properties and level of acceptance of the consumer formula which was declared optimal. Cherry leaves were extracted by maceration method using ethanol $96 \%$ solvent. Determination of the optimum value was carried out using the Simplex Lattice Design method available in the Design Expert software Version 11. The results showed that the optimum ointment formula had a composition of vaseline albumin and adeps lanae of $73,29 \%$ and $9,71 \%$, with a spreadability $3,10 \pm 0,12 \mathrm{~cm}$, adhesion $6,10 \pm 0,53$ seconds, $\mathrm{pH} 4,78 \pm 0,08$, and the acceptability value is 4,02 . So it can be concluded that the formula declared optimum has physical properties that meet the requirements and are liked by the respondents.
\end{abstract}

Keywords: Cherry Leaf (Muntingia calabura L.), Ointment, Simplex Lattice Design

\title{
PENDAHULUAN
}

Daun kersen (Muntingia calabura L.) merupakan salah satu tanaman yang memiliki aktivitas antibakteri. Aktivitas antibakteri daun kersen ini disebabkan oleh adanya kandungan senyawa tanin, flavonoid, dan saponin yang dimilikinya (Zakaria et al., 2006). Ekstrak etanol daun kersen pada konsentrasi 3 ppm, 5 ppm dan 9 ppm memiliki daya anti bakteri terhadap Staphylococcus epidermidis yang merupakan bakteri penyebab jerawat (Handayani, 2015). Nilai KBM daun kersen terhadap bakteri Staphylococcus aureus adalah 1,250 mg/ml (Manik dan Triana, 2014).

Formulasi sediaan krim dari daun kersen yang dilakukan oleh Puspitasari et al (2018) memiliki nilai daya lekat yang kurang baik karena tidak sesuai dengan persyaratan yaitu lebih dari 4 detik, yang menyebabkan tidak maksimalnya daya lekat krim tersebut pada kulit. Dikarenakan penelitian ini dimaksudkan untuk pengobatan pada kulit sebagai antibakteri, maka dibutuhkan suatu sediaan yang dapat melekat lama pada kulit. Bentuk sediaan salep dianggap cocok karena kontak antara obat dengan kulit lebih lama dan memiliki daya lekat yang baik, serta mempunyai konsistensi yang cocok sehingga mudah untuk digunakan (Sari dan Maulidya, 2016). Pemilihan basis salep merupakan salah satu hal yang harus diperhatikan dalam pembuatan salep karena dapat mempengaruhi sifat fisik dari sediaan tersebut. Basis salep yang akan digunakan yaitu basis salep serap air. Basis salep ini merupakan dasar salep berlemak yang dimaksudkan untuk memperpanjang kontak bahan obat dengan kulit dan digunakan terutama sebagai emolien (Farmakope Indonesia IV, 1995). 
Adapun tujuan dari penelitian ini adalah untuk mengetahui komposisi formula optimum ekstrak etanol daun kersen dengan variasi konsentrasi vaselin album dan adeps lanae, serta sifat fisik dan tingkat kesukaan konsumen pada formula yang dinyatakan optimum.

\section{BAHAN DAN METODE}

\section{Pembuatan Simplisia dan Ekstraksi}

Preparasi daun kersen dimulai dari determinasi, pembuatan simplisia dan ekstraksi. Daun kersen yang sudah tua dicuci, dikeringkan di bawah sinar matahari kemudian dibuat dalam bentuk serbuk dengan cara diblender (Puspitasari dan Lean, 2017). Setelah itu, 300 gram serbuk dimaserasi menggunakan pelarut etanol $96 \%$ selama $3 \times 24$ jam dengan pengadukan setiap 1x24 jam. Maserat disaring, dan filtrat diuapkan dengan Vaccum Rotary Evaporator hingga didapatkan hasil berupa ekstrak kental (Putri et al, 2018), yang ditandai dengan berat ekstrak yang konstan (Harborne, 1987).

\section{Skrining Fitokimia}

\section{Saponin}

Ekstrak kental ditambahkan akuades panas kemudian dididihkan selama 5 menit dan disaring. Filtrat dikocok selama 10 detik dan didiamkan selama 10 menit. Setelah itu ditambahkan 1 tetes $\mathrm{HCl} 2 \mathrm{~N}$. Hasil positif ditandai dengan terbentuknya busa yang stabil setelah didiamkan selama 10 menit dan ditambahkan $\mathrm{HCl}$ 2N (Nugrahani et al, 2016).

\section{Flavonoid}

Ekstrak kental dilarutkan dalam air panas, dididihkan selama 5 menit, lalu disaring. Filtrat yang didapatkan lalu ditambahkan serbuk $\mathrm{Mg}, 1 \mathrm{ml} \mathrm{HCl}$ pekat dan $2 \mathrm{ml}$ etanol 96\%. Tabung dikocok dan dibiarkan terpisah. Terbentuknya warna merah, merah ungu, kuning atau jingga pada lapisan etanol menunjukkan adanya senyawa flavonoid (Tiwari et al, 2011).

\section{Tanin}

Ekstrak kental ditambahkan aquadest, dipanaskan, lalu disaring. Kemudian ditambahkan 2 tetes $\mathrm{FeCl}_{3}$ 1\% (Ikalinus et al, 2015). Adanya tannin ditandai dengan timbulnya warna hijau kehitaman (Surbakti et al, 2018).

\section{Formulasi dan Optimasi Salep}

Tabel 1 Formula Salep Ekstrak Etanol Daun Kersen

\begin{tabular}{lc}
\hline \multicolumn{1}{c}{ Bahan Formula } & Konsentrasi (\%B/B) \\
\hline Ekstrak etanol daun kersen & 0,125 \\
Vaselin album & $65-78$ \\
Adeps lanae & $5-18$ \\
Stearil alkohol & 4,5 \\
Cera alba & 12 \\
Nipagin & 0,15 \\
Nipasol & 0,225 \\
Persen total & $100 \%$ \\
\hline
\end{tabular}


Tabel 2 Variasi Konsentrasi Vaselin Album dan Adeps Lanae

\begin{tabular}{ccc}
\hline Formula & \multicolumn{2}{c}{ Jumlah (\%) } \\
\cline { 2 - 3 } $\mathbf{1}$ & Vaselin Album & Adeps Lanae \\
$\mathbf{2}$ & 65 & 18 \\
$\mathbf{3}$ & 78 & 5 \\
$\mathbf{4}$ & 71,5 & 11,5 \\
$\mathbf{5}$ & 71,5 & 11,5 \\
$\mathbf{6}$ & 68,25 & 14,75 \\
$\mathbf{7}$ & 78 & 5 \\
$\mathbf{8}$ & 65 & 18 \\
\hline
\end{tabular}

Pembuatan salep dilakukan dengan melelehkan stearil alkohol dan cera alba di atas waterbath, lalu ditambahkan adeps lanae serta nipasol dan nipagin. Vaselin album ditambahkan dan diaduk hingga homogen. Setelah campuran meleleh, dipindahkan ke dalam mortar panas dan kemudian diaduk perlahan-lahan hingga membentuk sediaan massa salep. Selanjutnya campuran tersebut ditambahkan sedikit demi sedikit ke dalam mortar lain yang telah berisi ekstrak etanol daun kersen sambil diaduk hingga homogen (Sandy dan Yaumi, 2018). Tiap formula kemudian diuji sifat fisiknya berupa $\mathrm{pH}$, daya sebar, dan daya lekat.

\section{Uji Akseptabilitas}

Uji akseptabilitas dilakukan terhadap 20 sukarelawan dengan menggunakan angket. Pengujian dengan meminta tanggapan sukarelawan yang menggunakan salep berupa warna, aroma, tekstur, kemudahan dicuci dan kesan tidak lengket. Data diolah dengan merata-ratakan skor dari masingmasing parameter dan di rangking berdasarkan berikut :

$$
\begin{array}{ll}
1 & =\text { tidak suka } \\
2 & =\text { kurang suka } \\
3 & =\text { cukup suka } \\
4 & =\text { suka } \\
5 & =\text { sangat suka }
\end{array}
$$

\section{Analisis Data}

Optimasi formula optimum menggunakan metode Simplex Lattice Design dengan software Design Expert versi 11. Optimasi formula dilakukan dengan menentukan nilai lower limit dan upper limit dari vaselin album dan adeps lanae. Software akan memberi rekomendasi 8 formula, dimana ke- 8 formula selanjutnya diformulasi dan dievaluasi sifat fisiknya (daya sebar, daya lekat, dan $\mathrm{pH}$ ). Hasilnya kemudian dimasukkan kedalam software. Formula optimum yang ditentukan software kemudian diformulasi dan diuji sifat fisiknya kemudian dibandingkan dengan prediksi sifat fisik dari software Design Expert menggunakan analisis statistik One Sample t-test menggunakan software SPSS. 
HASIL

\section{Pembuatan Simplisia dan Ekstraksi}

Simplisia kering yang diperoleh yaitu 560 gram, dengan ekstrak kental sebesar 64,81 gram, berwarna coklat kehitaman, berbau khas ekstrak, berbentuk pasta, dan rendemen ekstrak sebesar $21,6 \%$.

\section{Skrining Fitokimia}

Tabel 3 Hasil Skrining Fitokimia Ekstrak Etanol Daun Kersen

\begin{tabular}{lcc}
\hline $\begin{array}{c}\text { Golongan } \\
\text { senyawa }\end{array}$ & $\begin{array}{c}\text { Hasil } \\
\text { identifikasi }\end{array}$ & Hasil yang terbentuk \\
\hline Flavonoid & + & Larutan berwarna merah \\
Tanin & + & Larutan berwarna hijau kehitaman \\
Saponin & + & Busa tidak hilang \\
\hline eterangan : (+) menunjukkan adanya golongan senyawa yang diuji
\end{tabular}

\section{Formulasi dan Optimasi Salep}

Tabel 4 Desain Eksperimental Formulasi Sediaan Salep Ekstrak Etanol Daun Kersen dan Responnya

\begin{tabular}{cccccc}
\hline Run & $\begin{array}{c}\text { A: } \\
\text { Vaselin album }\end{array}$ & $\begin{array}{c}\text { B: } \\
\text { Adeps lanae }\end{array}$ & $\begin{array}{c}\text { Daya sebar } \\
\text { (cm) }\end{array}$ & $\begin{array}{c}\text { Daya lekat } \\
\text { (detik) }\end{array}$ & pH \\
\hline $\mathbf{1}$ & 65,00 & 18,00 & 3,43 & 6,30 & 4,79 \\
$\mathbf{2}$ & 78,00 & 5,00 & 2,83 & 6,90 & 4,68 \\
$\mathbf{3}$ & 71,50 & 11,50 & 3,18 & 6,50 & 4,74 \\
$\mathbf{4}$ & 71,50 & 11,50 & 3,00 & 6,30 & 4,70 \\
$\mathbf{5}$ & 68,25 & 14,75 & 3,33 & 5,80 & 4,81 \\
$\mathbf{6}$ & 78,00 & 5,00 & 2,88 & 7,10 & 4,73 \\
$\mathbf{7}$ & 65,00 & 18,00 & 3,23 & 6,50 & 4,80 \\
$\mathbf{8}$ & 74,75 & 8,25 & 3,08 & 6,80 & 4,70 \\
\hline
\end{tabular}

Tabel 5 Data Hasil Analisis ANOVA Respon Daya Sebar, Daya Lekat dan pH dengan software Design Expert

\begin{tabular}{lccc}
\hline \multicolumn{1}{c}{ Parameter } & Daya sebar & Daya lekat & pH \\
\hline Model : linear mixture & 0,00 & 0,02 & 0,02 \\
Residual : lack of fit & 0,58 & 0,08 & 0,28 \\
R-square & 0,83 & 0,73 & 0,72 \\
Adjusted $R$-square & 0,76 & 0,62 & 0,61 \\
Predicted R-square & 0,55 & 0,42 & 0,34 \\
Adeq Precision & 7,61 & 5,48 & 5,43 \\
\hline
\end{tabular}

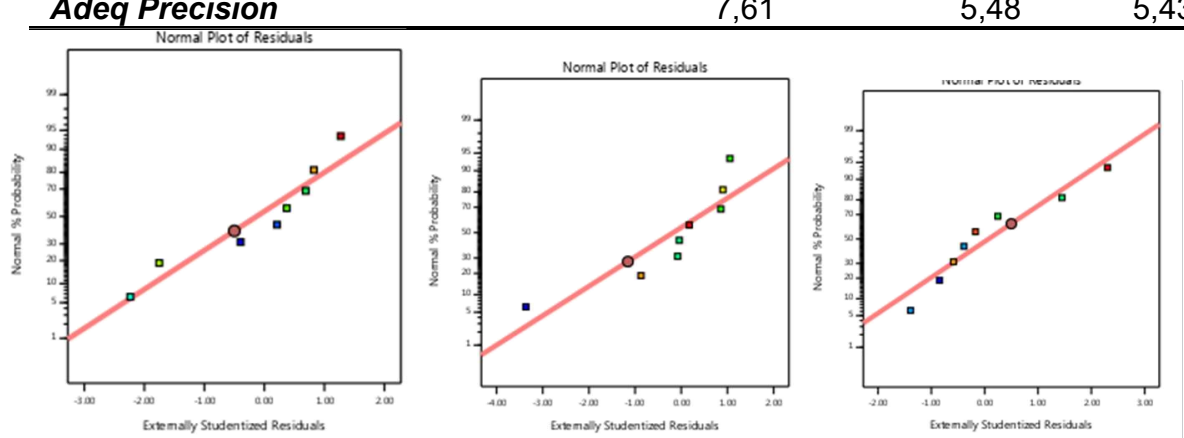

Gambar 1 Kurva Normal Plots of Residual respon daya sebar (a), daya lekat (b), pH (c) menunjukkan bahwa data menyebar di sekitar garis diagonal 
Tabel 6 Persamaan SLD masing-masing respon

\begin{tabular}{cc}
\hline Respon & Persamaan \\
\hline Daya sebar & $\mathrm{Y}=2,86(\mathrm{~A})+3,34(\mathrm{~B})+0,18(\mathrm{AB})$ \\
Daya Lekat & $\mathrm{Y}=7,06(\mathrm{~A})+6,31(\mathrm{~B})-1,47(\mathrm{AB})$ \\
$\mathrm{pH}$ & $\mathrm{Y}=4,70(\mathrm{~A})+4,80(\mathrm{~B})-0,08(\mathrm{AB})$ \\
\hline Keterangan & $\mathrm{Y}=$ Respon daya sebar/ daya lekat/ pH \\
& $\mathrm{A}=$ Konsentrasi Vaselin album \\
& $\mathrm{B}=$ Konsentrasi Adeps lanae
\end{tabular}

Tabel 7 Formula Optimum Sediaan Salep dan Perkiraan Respon

\begin{tabular}{|c|c|c|c|c|c|}
\hline & Komponen & & pon & & \\
\hline $\begin{array}{l}\text { Vaselin } \\
\text { album } \\
\text { (aram) }\end{array}$ & $\begin{array}{c}\text { Adeps lanae } \\
\text { (gram) }\end{array}$ & $\begin{array}{l}\text { Daya sebar } \\
\text { (cm) }\end{array}$ & $\begin{array}{l}\text { Daya lekat } \\
\text { (s) }\end{array}$ & $\overline{\mathrm{pH}}$ & Desirability \\
\hline 73,29 & 9,71 & 3,07 & 6,45 & 4,72 & 1,00 \\
\hline
\end{tabular}

Tabel 8 Verifikasi Formula Optimum Salep Ekstrak Etanol Daun Kersen

\begin{tabular}{lcccc}
\hline \multicolumn{1}{c}{ Respon } & Prediksi & Nilai & p-value & Kesimpulan \\
\hline Daya sebar & 3,07 & $3,10 \pm 0,12$ & 0,66 & Berbeda tidak signifikan \\
Daya lekat & 6,45 & $6,10 \pm 0,53$ & 0,27 & Berbeda tidak signifikan \\
pH & 4,72 & $4,78 \pm 0,08$ & 0,23 & Berbeda tidak signifikan \\
\hline
\end{tabular}

\section{PEMBAHASAN}

Hasil skrining flavonoid, tanin dan saponin menunjukkan hasil yang positif, dengan tanda seperti yang tertera dalam Tabel 3, dimana pada uji flavonoid terbentuk larutan berwarna merah setelah penambahan serbuk $\mathrm{Mg}$, pada uji tanin terbentuk larutan berwarna hijau kehitaman setelah penambahan $\mathrm{FeCl}_{3}$, dan busa yang tidak hilang pada uji saponin setelah penambahan $\mathrm{HCl}$ $2 \mathrm{~N}$. Hal ini sesui dengan penelitian yang dilakukan oleh Isnarianti et al (2013) yang mengatakan bahwa daun kersen mengandung senyawa flavonoid, tanin, dan saponin yang dapat berfungsi sebagai antibakteri.

Uji homogenitas pada Gambar 1 menunjukkan bahwa pada ketiga respon (daya sebar, daya lekat dan $\mathrm{pH}$ ), data tersebar disekitar garis diagonal dan mengikuti arah garis diagonal, sehingga dapat dikatakan bahwa data homogen. Selanjutnya, masing-masing respon diuji ANOVA. Kriteria dari hasil analisis yang akan dipilih diantaranya yaitu yang menghasilkan nilai $\mathrm{R}^{2}$ yang terbesar (mendekati 1), model linear mixture signifikan, lack of fit ( $F$-value) $>0,05$ (tidak signifikan), nilai Adjusted $R$-square dan Predicted $R$-square yang berdekatan paling tidak berjarak 0,2 , serta model yang memiliki nilai Adeq Precision yang tinggi (lebih dari 4). Nilai $\mathrm{R}^{2}$ terbesar menunjukkan bahwa model tersebut disarankan, sedangkan nilai Lack of Fit yang tidak signifikan merupakan syarat untuk model yang baik karena menunjukkan adanya kesesuaian data respon dengan model (Ramadhani et $a l, 2017)$. Berdasarkan penelitian yang dilakukan, semua kriteria tersebut dimiliki oleh ketiga respon baik daya sebar, daya lekat maupun $\mathrm{pH}$, sebagaimana dapat dilihat dalam Tabel 4.

Melalui software design expert didapatkan persamaan yang menyatakan nilai fungsi dari daya sebar, daya lekat dan $\mathrm{pH}$ sebagai respon. Persamaan tersebut dapat dilihat pada Tabel 6 Pada tabel tersebut untuk respon daya sebar, adeps lanae merupakan komponen yang paling besar pengaruhnya. Hal ini sesuai dengan penelitian Astuti et al (2007) bahwa adeps lanae 
memiliki kemampuan menyerap air hingga duakali beratnya, sehingga dapat memperbesar nilai daya sebar salep. Secara tunggal, jumlah vaselin album dan adeps lanae berpengaruh positif terhadap daya sebar. Vaselin album dapat menurunkan konsistensi sediaan salep sehingga salep lebih encer dan menyebabkan daya sebar meningkat (Sandi dan Yaumi, 2018). Kombinasi antara kedua komponen dapat memperbesar daya sebar salep.

Sedangkan untuk respon daya lekat, vaselin album merupakan komponen yang paling besar pengaruhnya. Hal ini ditunjukkan dengan koefisien vaselin album yaitu $+7,06$. Secara tunggal, jumlah vaselin album dan adeps lanae berpengaruh positif terhadap daya lekat. Namun, peningkatan konsentrasi dari kombinasi bahan tersebut dapat menurunkan daya lekat sediaan. Vaselin album dan adeps lanae merupakan basis berlemak yang dapat menurunkan viskositas sehingga konsistensinya lebih lembek (Naibaho et al, 2013).

Adapun untuk respon $\mathrm{pH}$, adeps lanae merupakan komponen yang paling besar pengaruhnya terhadap respon $\mathrm{pH}$ dibandingkan vaselin album walaupun perbedaan nilai $\mathrm{pH}$ dapat dikatakan sangat kecil (dapat dikatakan bahwa variasi konsentrasi basis tidak begitu mempengaruhi $\mathrm{pH}$ sediaan). Hal ini sesuai dengan penelitian Fatimah (2017) yang mengatakan bahwa variasi konsentrasi basis salep tidak berpengaruh pada $\mathrm{pH}$ sediaan. Secara tunggal, jumlah vaselin album dan adeps lanae berpengaruh positif terhadap respon $\mathrm{pH}$. Namun, peningkatan konsentrasi dari kombinasi bahan tersebut dapat menurunkan $\mathrm{pH}$ sediaan.

Formula optimum yang disarankan oleh software Design Expert dapat dilihat pada Tabel 7. Berdasarkan tabel tersebut, nilai desirability yang diperoleh adalah 1,00. Formula yang paling optimal adalah formula dengan nilai desirability maksimum. Nilai desirability (tingkat keinginan) yang semakin mendekati nilai 1,00 menunjukkan semakin tingginya kesesuaian proses optimasi yang optimal dengan variable respon yang dikehendaki (Engelen, 2015).

Verifikasi formula optimum menunjukkan bahwa ketiga respon formula yang dinyatakan optimum memenuhi persyaratan, dimana daya sebar lebih dari $3 \mathrm{~cm}$ yaitu $3,10 \pm 0,12 \mathrm{~cm}$ yang menunjukkan bahwa sediaan yang dibuat merupakan sediaan semisolid berupa semistiff (sediaan yang memiliki viskositas tingi). Perbedaan daya sebar sangat berpengaruh pada kecepatan difusi zat aktif dalam melewati membran, dimana semakin luas membran tempat sediaan menyebar maka koefisien difusi makin besar yang mengakibatkan difusi obat pun semakin meningkat, Hal ini sesuai dengan penelitian Kuntari et al (2019) yang mengatakan bahwa semakin besar jumlah lubang (luas permukaan besar), maka semakin cepat penurunan konsentrasi yang terjadi (arus difusi semakin besar), sehingga semakin besar daya sebar suatu sediaan maka akan semakin meningkat difusinya ke dalam kulit (Naibaho et al, 2013). Daya sebar yang memenuhi syarat ini menunjukkan bahwa adeps lanae memiliki kemampuan untuk menahan air sehingga dapat memperbesar nilai daya sebar salep. Adapun vaselin album dapat menurunkan konsistensi sediaan salep sehingga salep lebih encer dan menybabkan daya sebar meningkat (Sandi dan Yaumi, 2018). Daya lekat yang baik menurut Yunita (2016) adalah tidak kurang

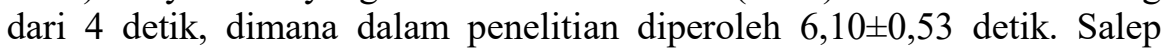
dikatakan baik jika daya lekatnya besar pada tempat yang diobati (kulit), karena zat aktif tidak mudah lepas sehingga dapat menghasilkan efek yang diinginkan (Ulaen, 2012). Adapun nilai $\mathrm{pH}$ yang diperoleh sesuai dengan range $\mathrm{pH}$ untuk sediaan topical yaitu 4,5-8 (Badan Standarisasi Nasional, 
1996) dengan nilai $4,78 \pm 0,08$ yang menunjukkan bahwa salep tidak mengiritasi kulit dan nyaman digunakan.

Pada Tabel 8 dapat dilihat bahwa semua nilai respon memiliki $p$-value yang lebih besar dari 0,05 yang menunjukkan bahwa data hasil percobaan tidak berbeda signifikan dengan data hasil prediksi software Design Expert versi 11 . Hasil verifikasi ini memastikan bahwa optimasi dengan software design expert dapat diterima. Formula optimum kemudian diuji tingkat akseptabilitasnya. Penilaian menggunakan angka 1 sampai 5, dimana angka 1 berarti tidak disukai dan angka 5 berarti sangat disukai. Data akseptabilitas diolah dengan merata-ratakan skor dari masing-masing parameter, dan diperoleh nilai akseptabilitas 4,02 yang menandakan bahwa salep ekstrak etanol daun kersen yang dinyatakan optimum disukai oleh responden.

\section{SIMPULAN}

Berdasarkan penelitian yang telah dilakukan dapat disimpulkan bahwa formula optimum pada sediaan salep ekstrak etanol daun kersen (Muntingia calabura L.) adalah salep dengan komposisi konsentrasi vaselin album $73,29 \%$ dan adeps lanae $9,71 \%$. Adapun sediaan salep yang dinyatakan optimum memiliki sifat fisik dan akseptabilitas yang baik.

\section{REFERENCE}

Astuti, I.Y., Iskandar S., Umi H., 2007, Pengaruh Konsentrasi Adeps Lanae dalam Dasar Salep Cold Cream terhadap Pelepasan Asam Salisilat, Pharmacy., 5(1): P. 22-29.

Badan Standarisasi Nasional, 1996, Sediaan Tabir Surya, Badan Standarisasi Nasional, Jakarta. SNI 16-4399-1996.

Engelen, A., 2015, Optimasi Proses dan Formula pada Karakteristik Kelengketan Mi Sagu, Jtech, (1): 39-46.

Fatimah, Y., 2017, Pengaruh Basis Salep terhadap Sifat Fisik Sediaan Salep Ekstrak Etanolik Bonggol Pisang Ambon (Musa Paradisiaca Var. Sapientum L.) Sebagai Penyembuhan Luka Terbuka Pada Tikus, Skripsi., Universitas Muhammadiyah Surakarta.

Harborne, J.B., 1987, Metode Fitokimia Penuntun Cara Modern Menganalisa Tumbuhan, Bandung : ITB

Ikalinus, R., Sri, K.W., dan Ni, L.E.S., 2015, Skrining Fitokimia Ekstrak Etanol Kulit Batang Kelor (Moringa oleifera), Indonesia Medicus Veterinus., 4(1): 71-79.

Isnarianti, R, I., Wahyudi., Puspita R., 2013, Muntingia calabura L Leaves Extract Inhibits Glucosyltransferase Actifity of Streptococcus mutans. Journal of Dentistry Indonesia., 20(3): 59-63.

Kuntari, F.R., Susatyo, P., dan Adita S, 2019, Studi Proses Difusi melalui Membran dengan Pendekatan Kompartemen, Jurnal Fisika dan Aplikasinya, 15(2):62-65.

Manik, D.F., dan Triana H., 2014, Analisis Korelasi Antara Kadar Flavonoid dengan Aktivitas Antibakteri Ekstrak Etanol dan Fraksi-fraksi Daun Kersen (Muntingia calabura L) terhadap Staphylococcus aureus, Khazanah., 6(2): 1-11.

Naibaho, O.H., Paulina, V.Y.Y., dan Weny, W., 2013, Pengaruh Basis Salep terhadap Formulasi Sediaan Salep Ekstrak Daun Kemangi (Ocimum sanctum L.) pada Kulit Punggung Kelinci yang Dibuat Infeksi Staphylococcus aureus, Jurnal Ilmiah Farmasi-UNSRAT., 2(2): 27-34.

Nugrahani, R., Yayuk A., dan Aliefman H., 2016, Skrining Fitokimia dari Ekstrak Buah Buncis (Phaseolus vulgaris L.) dalam Sediaan Serbuk, Jurnal Penelitian Pendidikan IPA., 2(1): 35-42.

Puspitasari, A.D dan Lean S. P., 2017, Perbandingan Metode Ekstraksi Maserasi Dan Sokletasi terhadap Kadar Fenolik Total Ekstrak Etanol Daun Kersen (Muntingia calabura), Jurnal Ilmiah Cendekia Eksakta., 2(1): 1-8.

Puspitasari, A.D., Dewi A.K.M., dan Herlina, 2018, Formulasi Krim Tabir Surya Ekstrak Etanol Daun Kersen (Muntingia calabura L.) untuk Kesehatan Kulit, Media Litbangkes, 28(4): 263-270. 
Putri, C.A., Yuliet Dan Khildah K., 2018, Efektivitas Ekstrak Daun Kersen (Muntingia calabura L.) terhadap Penurunan Kadar Kolesterol Total Tikus Putih Jantan (Rattus Norvegicus L.) yang Diinduksi Pakan Tinggi Lemak, Biocelebes., 12(1): 65-72.

Ramadhani, R.A., Dody, H.S.R., Bayu, T., Ratna, D.K. 2017, Revew Pemanfaatan Design Expert untuk Optimasi Komposisi Campuran Minyak Nabati sebagai Bahan Baku Sintesis Biodiesel. Jurnal Teknik Kimia dan Lingkungan., 1(1): 11-16.

Sandi, D.A.D, Yaumi M., 2018, Pengaruh Basis Salep Hidrokarbon dan Basis Salep Serap Terhadap Formulasi Salep Sarang Burung Walet Putih (Aerodramus fuciphagus), Jurnal Ilmiah Manuntung., 4(2): 149-155.

Sari, A dan Maulidya, A., 2016, Formulasi Sediaan Salep Ekstrak Etanol Rimpang Kunyit (Curcuma longa Linn), Jurnal Ilmia., 3(1): 16-23.

Surbakti,P.A.A., Edwin, D.Q., Waddhih, B., 2018, Skrining Fitokimia dan Uji Toksisitas Ekstrak Etanol Daun Binahong (Andredera cordifolia (Ten) Steenis) dengan Metode Brine Shrimplethality Test (BSLT), Jurnal Ilmiah Farmasi-UNSRAT.,7(3): 22-31.

Tiwari, P., Kumar, B., Kaur, G., Kaur, H., 2011, Phytocemical Screening and Extraction: A Revew, Internationale Pharmaceutica Sciencia., 1(1): 98-106.

Ulaen, S.P.J., Banne, Y., Suatan,. R.A,, 2012, Pembuatan Salep Anti Jerawat dari Ekstrak Rimpang Temulawak (Curcuma xanthorrhiza Roxb.). Jurnal Ilmiah. Politeknik Kesehatan Kemenkes Manado., 3(2): 45-49.

Yunita, I., 2016, Uji Sifat Fisik Formulasi Salep Ekstrak Rimpang Kunyit (Curcuma longa L) dengan Basis Hidrokarbon dan Larut Air. Skripsi, Banjarmasin :Universitas Muhammadiyah Banjarmasin.

Zakaria, Z.A et al., 2006, The In Vitro Antibacterial Activity of Muntingia calabura Extracts. Int, J. Pharmacol., 2( 4): 439-442.

\section{UCAPAN TERIMA KASIH}

Ucapan terimakasih disampaikan kepada semua pihak yang terlibat dalam membantu penelitian dan kepada dosen pembimbing yang telah memberikan arahan dan masukan sehingga penelitian ini dapat berjalan dengan lancar

\section{KONTRIBUSI PENULIS}

Baiq Saomi Alfilaili berperan dalam mengumpulkan data, interpretasi data dan membuat naskah. Wahida Hajrin dan Yohanes Juliantoni berperan dalam membimbing dan mengarahkan dalam penelitian. Semua penulis berkontribusi dalam penelitian dan menyetujui versi akhir naskah.

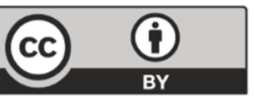

Akses Terbuka Artikel ini dilisensikan di bawah Creative Commons Lisensi Internasional Attribution 4.0, yang memungkinkan penggunaan, berbagi, adaptasi, distribusi, dan reproduksi dalam media atau format apa pun, selama Anda memberikan kredit yang sesuai kepada penulis asli dan sumbernya, memberikan tautan ke lisensi Creative Commons, dan menerangkan jika perubahan telah dilakukan. Gambar atau materi pihak ketiga lainnya dalam artikel ini termasuk dalam lisensi Creative Commons artikel, kecuali dinyatakan sebaliknya dalam batas kredit untuk materi tersebut. Jika materi tidak termasuk dalam lisensi Creative Commons artikel dan penggunaan yang Anda maksudkan tidak diizinkan oleh peraturan perundang-undangan atau melebihi penggunaan yang diizinkan, Anda harus mendapatkan izin langsung dari pemegang hak cipta. Untuk melihat salinan lisensi ini, kunjungi https://creativecommons.org/licenses/by/4.0/deed.id.

(C) The Author(s) 2021 